\title{
The Residue of Seed Harvest From Tropical \\ Grasses as a Roughage Source in the Feedlot Lambs Diet
}

Camila Celeste Brandão Ferreira Ítavo, Luis Carlos Vinhas Ítavo (Corresponding author)

Federal University of Mato Grosso do Sul, Faculty of Veterinary Medicine and Animal Science, Campo Grande, Mato Grosso do Sul, Brazil. E-mail: luis.itavo@ufms.br

Cacilda Borges do Valle

Brazilian Agricultural Research Corporation, Embrapa Beef Cattle, Campo Grande, Mato Grosso do Sul, Brazil

Alexandre Menezes Dias, Gelson do Santos Difante, Marina de Nadai Bonin Gomes, Antonio Leandro Chaves Gurgel, Claudia Muniz Soares, Pâmila Carolini Gonçalves da Silva, Kedma Leonora Silva Monteiro Ferell, Jonilson Araújo Silva, Thais Fernanda Farias de Souza Arco

Federal University of Mato Grosso do Sul, Faculty of Veterinary Medicine and Animal Science, Campo Grande, Mato Grosso do Sul, Brazil

Received: Sep. 11, 2019 Accepted: Sep. 23, $2019 \quad$ Published: Sep. 24, 2019

doi:10.5296/jas.v7i4.15517～URL: https://doi.org/10.5296/jas.v7i4.15517

\begin{abstract}
Our hypothesis was whether the residue of seed harvest from tropical grasses (Brachiaria sp. and Panicum sp.) as roughage source might result in the similar performance of lambs confined to obtain sustainability in agricultural and food systems by use of this by-product. This study was aimed to evaluate the effects of the residue of seed harvest (straw-hay) from tropical grasses as a roughage source in the feedlot lamb diet on intake, digestibility, performance, carcass characteristics and meat quality. The randomized block design used 36 lambs (six animals per treatment) distributed in six treatments arranged in individual cages on performance assay. The offered straw-hay did not influence nutrient intake and digestibility. Chewing was influenced by straw-hays. In addition, an effect was not observed on the length of the carcass, length of the leg, width and perimeter of the croup, depth of the chest or weight of the left half of the carcass. The averages of gammon, palette and neck yields were considered satisfactory, which may have been caused by the high content of neutral detergent fiber that was offered (511.4 g/Kg for Tupi and $617.6 \mathrm{~g} / \mathrm{Kg}$ for Basilisk), and the weight of
\end{abstract}


the palette and gammon can result in high commercial value. The meat characteristic was affected by a straw-hay. Diets containing residue of seed harvest from tropical grasses (Brachiaria sp. and Panicum sp.) as a roughage source did not have any effect on the dry matter and crude protein consumption and on the growth performance. So, we recommend the residue of seed harvest from tropical grasses as a fiber source to feedlot lamb diet.

Keywords: fiber source, ruminant nutrition, tropical pastures, sheep nutrition, straw

\section{Introduction}

Pastures are the staple diet of ruminants in Brazil, highlighting the need to identify the most effective way of feeding livestock. Brachiaria sp. cultivars are important in the establishment of pastures because they make enable ruminant production even in the low fertility soils (Fernandez et al. 2015). Such genders, mainly tropical of African origin, comprise approximately 100 species, including Brachiaria decumbens, B. humidicola and $B$. ruziziensis, which are widely used as fodder plants in tropical biomes. The highlight of Brazil on the world stage as a livestock producer is due to, among other factors, the exploitation of the productive potential of tropical grasses. The Brachiaria sp. have high biomass accumulation rates during the rainy season and can, when well managed, present structural characteristics and nutritional value compatible with good animal performance (Oliveira et al. 2015a; Silva et al. 2015a).

The quality of the forage is an important factor related to consumption, where the animal's physical ability to harvest the forage grass and the structural effects are crucial in controlling of the food intake. In recent years (Silva et al. 2014; Lima et al. 2015), some Brachiaria sp. and Panicum sp. Cultivars were recommended for the sheep's nutrition. The hay produced from cultivars of Brachiaria sp. and Panicum sp. may provide the best performance for animals in terms of body composition, which can be extremely important at the time of theirs marketing by adding value to the product and increasing the profits to the producer. Thus, to evaluate the forage potential on lamb nutrition, an evaluation of the dry matter intake and digestibility of its constituents and performance is needed (Moreira et al. 2014; Silva et al. 2015b).

However, to select and recommends the best grasses, the animals must be characterized by measuring the lamb carcasses and correlating their tissues with the structural conformations that can be used to predict the average daily gain in live weight and carcass yield (Ahmed et al. 2015).

Our performed study is based on the hypothesis how to evaluate whether the different straw-hays included in total mix ration might result in similar performance and quality of carcass of lambs in confinement to obtain sustainability in agricultural and food systems by use of this by-product. Furthermore, there is a need to test new cultivars such as: Piatã (Brachiaria brizantha), Tupi (Brachiaria humidicola) and Massai (Panicum maximum), in lamb diets, since these grasses were recommended as a good diet for sheep. However, due to high demand for seeds, there are no studies about use of residue of seed harvest from tropical grasses as a roughage source to confirm best performances for lambs when these forages in 
straw-hay form are used. In this way, it was evaluated the nutrient intake and performance, carcass characteristics and cut yields of lambs fed diets containing straw-hay from Brachiaria sp. and Panicum sp. cultivars.

\section{Material and Methods}

The experiments were carried out at the Animal Metabolism Laboratory of the Faculty of Veterinary Medicine and Animal Sciences of the Federal University of Mato Gross do Sul (UFMS), in Campo Grande, Brazil. This work was approved by the Local Ethical Committee for use of animals in experiments of the UFMS (protocol $n^{\circ} 367 / 2011$ ). Animals were cared for according to the guidelines of the Ethics, Bioethics and Animal Welfare Committee of the Brazilia. (Conselho Federal de Medicina Veterinária, 2010).

\subsection{Animals, Treatment Diets and Experimental Design}

Thirty-six Dorper $\times$ Texel $\times$ Suffolk crossbred intact male lambs aged 4 months and with an average initial body weight of $16.8 \pm 4.39 \mathrm{Kg}$ were used to evaluate the effects of straw-hays from different cultivars of Brachiaria and Panicum in the diet on intake, performance and carcass and meat characteristics.

All lambs were vaccinated against clostridia and throughout the experiment received anthelmintic treatment (Cydectin, Fort Dodge Saúde Animal Ltda., São Paulo, SP, Brazil) according to regular FEC analyses (faecal egg counts per gram). Lambs were stratified by body weight in a completely randomized design for an 84-day experiment. They were housed in individual $3 \mathrm{~m}^{2}$ pens with wood slatted floor and had free access to water. Lambs were assigned into six treatments (six lambs/treatment) consisting in six residue of seed harvest from tropical grasses (straw-hay) as a roughage source in the total mixed ration.

They were evaluated six straw-hays from four cultivars from Brachiaria sp. (B. brizantha cv. Marandu and cv. Piata; B. decumbens cv. Basilisk and B. humidicola cv. Tupi) and two forms of Panicum sp. cultivars (Panicum maximum cv. Massai and P. maximum cv. Mombaca) with concentrate supplementation based on soybean meal and ground corn.

Diets were formulated to be isonitrogenous (170 g/kg crude protein DM basis) and to meet or exceed the National Research Council (NRC, 2007) for finishing lambs with an average body weight of $20 \mathrm{Kg}$, a potential gain of $200 \mathrm{~g} /$ day and average daily gain of $150 \mathrm{~g} /$ day (Table 1). 
Table 1. Chemical composition of hay and total mixed diets

\begin{tabular}{|c|c|c|c|c|c|c|}
\hline & \multicolumn{6}{|c|}{ Roughage } \\
\hline & \multicolumn{4}{|c|}{ Brachiaria } & \multicolumn{2}{|c|}{ Panicum } \\
\hline & $\begin{array}{c}\text { Marandu } \\
\text { B.brizantha }\end{array}$ & $\begin{array}{c}\text { Piatã } \\
\text { B.brizantha }\end{array}$ & $\begin{array}{c}\text { Basilisk } \\
\text { B.decumbens }\end{array}$ & $\begin{array}{c}\text { Tupi } \\
\text { B.humidicola }\end{array}$ & $\begin{array}{c}\text { Mombaça } \\
\text { P.maximum }\end{array}$ & $\begin{array}{c}\text { Massai } \\
\text { P.maximum }\end{array}$ \\
\hline \multicolumn{7}{|c|}{ Chemical composition of tropical grass straw-hay } \\
\hline $\mathrm{DM}(\mathrm{g} / \mathrm{Kg})$ & 931.2 & 937.0 & 931.2 & 928.0 & 905.7 & 915.9 \\
\hline $\mathrm{OM}(\mathrm{g} / \mathrm{Kg} \mathrm{DM})$ & 990.7 & 991.9 & 991.3 & 991.1 & 990.9 & 990.9 \\
\hline $\mathrm{CP}(\mathrm{g} / \mathrm{Kg} \mathrm{DM})$ & 18.4 & 20.9 & 34.9 & 30.1 & 39.0 & 31.7 \\
\hline $\mathrm{NDF}(\mathrm{g} / \mathrm{Kg} \mathrm{DM})$ & 859.9 & 888.6 & 840.2 & 807.4 & 871.0 & 856.3 \\
\hline $\mathrm{ADF}(\mathrm{g} / \mathrm{Kg} \mathrm{DM})$ & 577.5 & 636.1 & 539.4 & 512.7 & 535.9 & 594.3 \\
\hline $\mathrm{ADL}(\mathrm{g} / \mathrm{Kg} \mathrm{DM})$ & 81.6 & 218.2 & 114.8 & 73.4 & 85.1 & 110.5 \\
\hline \multicolumn{7}{|c|}{ Chemical composition of diets $\dagger$} \\
\hline $\mathrm{DM}(\mathrm{g} / \mathrm{Kg})$ & 876.3 & 864.8 & 845.7 & 877.7 & 863.5 & 882.2 \\
\hline $\mathrm{OM}(\mathrm{g} / \mathrm{Kg} \mathrm{DM})$ & 955.3 & 949.9 & 945.9 & 940.1 & 934.2 & 946.2 \\
\hline $\mathrm{CP}(\mathrm{g} / \mathrm{Kg} \mathrm{DM})$ & 176.7 & 177.9 & 170.7 & 168.3 & 172.1 & 169.0 \\
\hline $\mathrm{NDF}(\mathrm{g} / \mathrm{Kg} \mathrm{DM})$ & 548.7 & 533.3 & 617.6 & 511.4 & 512.1 & 555.7 \\
\hline $\mathrm{ADF}(\mathrm{g} / \mathrm{Kg} \mathrm{DM})$ & 273.6 & 270.0 & 303.3 & 235.3 & 225.7 & 303.7 \\
\hline $\mathrm{ADL}(\mathrm{g} / \mathrm{Kg} \mathrm{DM})$ & 40.9 & 47.4 & 57.0 & 41.7 & 47.9 & 65.6 \\
\hline
\end{tabular}

$\dagger$ Diets contained ground corn and soybean meal in the roughage at a forage to concentrate ratio of 500 to 500 on a DM basis, which was formulated according to the NRC (2007) for an average daily gain of $200 \mathrm{~g}$.

Diets for ad libitum intake (50 g/Kg orts, on an as-fed basis) were offered individually twice a day ( $08 \mathrm{~h} 00$ and 17h00). All straw-hays of tropical grass were chopped to the $5 \mathrm{~mm}$ length, were used as roughage at a forage to concentrate ratio of 500 to $500 \mathrm{w} / \mathrm{w}$ on a DM basis. The animals received a mineral mixture with guaranteed levels (per $\mathrm{Kg}$ in active elements) as follows: calcium $120.0 \mathrm{~g}$; phosphorus $87.0 \mathrm{~g}$; sodium $147.0 \mathrm{~g}$; sulfur $18.0 \mathrm{~g}$; copper $590.0 \mathrm{mg}$; cobalt $40.0 \mathrm{mg}$; chromium $20.0 \mathrm{mg}$; iron $1,800.0 \mathrm{mg}$; iodine $80.0 \mathrm{mg}$; manganese $1,300.0 \mathrm{mg}$; selenium $15.0 \mathrm{mg}$; zinc $3,800.0 \mathrm{mg}$; molybdenum $300.0 \mathrm{mg}$; maximum fluorine $870.0 \mathrm{mg}$; phosphorus (P) solubility in citric acid of $20 \mathrm{~g} / \mathrm{Kg}$ (minimum) to $950 \mathrm{~g} / \mathrm{Kg}$; dry matter (DM) basis of $20 \mathrm{~g} / \mathrm{Kg}$.

Amounts offered and refused were weighed daily and registered for each lamb to determine feed intake. Lambs at the beginning of the experiment and every 2 weeks for the 84-day experiment were weighed. Feed for $16 \mathrm{~h}$ before weighing the lambs was withheld. Samples of diets and were collected weekly, kept at $-20^{\circ} \mathrm{C}$ and pooled by lamb for nutrient intake determinations. Composite samples of diets and were dried at $55^{\circ} \mathrm{C}$ for $48 \mathrm{~h}$ and ground through a $1 \mathrm{~mm}$ screen in a Wiley mill (Marconi MA340, Piracicaba, SP, Brazil) for further analyses.

\subsection{Data Collection and Analysis}

Dry matter of diets, and feces were determined by drying samples in an oven at $105^{\circ} \mathrm{C}$ overnight (AOAC, 2000; method 930.15). All samples were dried in a forced-air oven at $55^{\circ} \mathrm{C}$ for $96 \mathrm{~h}$ and ground through a $1 \mathrm{~mm}$ mesh before analyses of $\mathrm{N}$, ether extract, ADF, and NDF. Total N was determined with a Tecnal TE-036/1 (Tecnal, Piracicaba, Brazil) according to method 976.05 of the AOAC (2000). The ether extract was conducted with Tecnal TE-044/1 following method 920.39 of the AOAC (2000). Ash content was determined by incineration at $600^{\circ} \mathrm{C}$ for $2 \mathrm{~h}$ in a muffle furnace (AOAC, 2000; method 942.05) and the 
organic matter content was calculated as the difference between 100 and the percentage of ash. Determination of neutral detergent fiber (NDF) was performed according to Mertens (2002) using a heat-stable $\alpha$-amylase (Termamyl 120 L $^{\circledR}$ Sigma-Aldrich, 3050 Spruce Street, Saint Louis, MO, USA) and without sodium sulfite, and expressed inclusive of residual ash. Acid detergent fiber (ADF) inclusive of residual ash and lignin concentrations were determined by solubilisation of cellulose with sulphuric acid $\left(\mathrm{H}_{2} \mathrm{SO}_{4}\right)$ using the methods of Robertson and Van Soest (1981). Total carbohydrates were calculated through the equation: total carbohydrates $=1000-(\mathrm{CP}+$ ether extract + ash $)$, while non-fibrous carbohydrates (NFC) were obtained using the equation proposed by Sniffen et al. (1992), where NFC = total carbohydrates - NDF.

From days 15 to 16,29 to 30,43 to 44 , and 57 to 58 of the feeding experiments, the total collection of faeces were conducted. Faeces were collected by fitting all lambs with a harness the day before initiating the faecal collection. Samples of feed and orts? were taken daily during the faeces collection and pooled on an 8-d basis for further analyses, with one pooled sample of feed and orts analysed for each treatment diet and lamb, respectively. Daily output of faeces was determined, and all faeces were frozen at $-20^{\circ} \mathrm{C}$ and accumulated for the 8-day collection. Thereafter, the faecal samples were thawed and mixed thoroughly; a subsample was collected, freeze-dried and ground to pass through the $1 \mathrm{~mm}$ screen using a Wiley mill for later analysis.

\subsection{Feeding Behaviour Measurements}

Feeding behaviour was monitored visually for a $24 \mathrm{~h}$ period on days 14, 28, 42, and 56 of the experiment, to a 10 min scanning interval and with $60 \mathrm{sec}$ scans. The numbers of bolus per lamb were determined during three different periods (10:00 to 12:00, 14:00 to 16:00, and 18:00 to 20:00 h) for each of the 4 days of feeding behaviour monitoring.

\subsection{Carcass Characteristics}

After 84 days, lambs were fasted for $16 \mathrm{~h}$ and weighed to determine body weight at slaughter. Thereafter, lambs were transported to the slaughterhouse in Campo Grande-MS, Brazil. Lambs were knocked unconscious using a captive bolt pistol and exsanguinated without electrical stimulus in accordance with the guidelines of the Brazilian Federal Inspection Service. All carcasses were weighed to determine hot carcass weight, refrigerated at $4^{\circ} \mathrm{C}$ for approximately $24 \mathrm{~h}$ and then take from the cooling chambers and weighed again to determine cold carcass weight. The difference between the chilled carcass weight and hot carcass weight were used to calculate carcass shrink loss. Internal and external carcass length, the perimeter of the croup, and depth of the chest were determined on cold carcasses as described by Osório et al. (1996a, 1996b). Carcass compactness index was calculated from the relationship between cold carcass and internal carcass length. Thereafter, the carcass was split into two identical longitudinal halves. In the left half of each carcass, the commercial cut yield was measured by separating the carcass half into the shoulder, fore shank loin, neck, rib, leg, and hind shank (Cartaxo et al. 2009) and the loin was separated into T-bone, tenderloin filet and rack. The palette was the sum of shoulder and fore shank, and the gammon was the sum of leg plus hind shank. The weight of each cut by total weight of the cool carcass was 


\section{Macrothink

divided to obtain the retail yield. Also, one sample was collected from the cross-section between the 9th and 11th rib on the left side of the carcass and dissected into lean, fat and bone tissues; each component was expressed as a percentage of the total weight of the rib sample to estimate physical composition. Subcutaneous fat was measured using a calipers rule on the left side of the carcass between the 12th and 13th ribs at the carcass midline.

\subsection{Statistical Analysis}

All data were submitted to analysis of variance using the GLM procedure of SAS (SAS Institute, Inc., 2002) according to the completely randomized design. Main sources of variation were straw-hays. Data of the carcass measurements were analyzed by the slaughter weight as covariant. Feed intake and the feed to gain ratio were analyzed using pen as the experimental unit and the lamb was the experimental unit for data about performance and carcass. Significance was declared at $\mathrm{P} \leq 0.05$ and a trend at $0.05<\mathrm{P}<0.10$, unless otherwise stated.

\section{Results}

The straw-hays from different cultivars of Brachiaria sp. and Panicum sp. as fiber source in the diet of lambs did not affect $(P>0.05)$ the intake and digestibility of DM, OM, CP, NDF and ADF (Table 2). When the DM intake was provided relative to body weight, the Mombaça variety of the Panicum genus $(43.9 \mathrm{~g} / \mathrm{kg} \mathrm{BW})$ showed the highest intake $(P=0.031)$. Higher lignin consumption $(P=0.024)$ was also observed for lambs fed the Massai variety $(0.65 \mathrm{~g} / \mathrm{kg})$. Among the diets formulated isoprotein $(170 \mathrm{~g} / \mathrm{kg})$ with $500 \mathrm{~g} / \mathrm{kg}$ hay, similarities were observed in the nutrient content, especially the NDF $(533 \mathrm{~g} / \mathrm{kg})$. The differences in the observed consumption of lignin (ADL) was justified by the higher lignin content in the diets composed of Panicum cv. Massai straw-hay $(67.1 \mathrm{~g} / \mathrm{kg})$ compared with Brachiaria cv. Tupi straw-hay $(41.7 \mathrm{~g} / \mathrm{kg}$ ) (Table 1). The differences in lignin content were most likely caused by the similarity in the DM intake, although they were not sufficient to alter the digestibility or production performance. However, the straw-hays from different cultivars in lamb diets influenced the behaviors ingestive. Chewing was higher in the animals that received Mombaça straw-hay (74 chewing/bolus). The chewing rate was increased $(P=0.005)$ by inclusion of Basilisk straw-hay in the diet, probably because of lignin content in this straw-hay $(218.2 \mathrm{~g} / \mathrm{kg} \mathrm{DM})$. 
Table 2. The nutrient intake and performance of lambs fed diets containing straw-hay from the cultivars of Brachiaria sp. and Panicum sp. in the diet

\begin{tabular}{|c|c|c|c|c|c|c|c|c|}
\hline & \multicolumn{6}{|c|}{ Roughage } & \multirow{3}{*}{ SEM } & \multirow{3}{*}{$P$} \\
\hline & \multicolumn{4}{|c|}{ Brachiaria } & \multicolumn{2}{|c|}{ Panicum } & & \\
\hline & $\begin{array}{c}\text { Marandu } \\
\text { B.brizantha }\end{array}$ & $\begin{array}{c}\text { Piatã } \\
\text { B.brizanthc }\end{array}$ & $\begin{array}{c}\text { Basilisk } \\
\text { B.decumbe }\end{array}$ & $\begin{array}{c}\text { Tupi } \\
\text { humidicola }\end{array}$ & $\begin{array}{l}\text { Mombaça } \\
\text { P.maximun }\end{array}$ & $\begin{array}{c}\text { Massai } \\
\text { P.maximum }\end{array}$ & & \\
\hline \multicolumn{9}{|c|}{ Nutrient intake } \\
\hline DM (Kg/day) & 0.9 & 0.8 & 0.8 & 1.0 & 1.1 & 1.0 & 0.03 & 0.547 \\
\hline $\begin{array}{l}\mathrm{DM} \\
\mathrm{BW}) \quad(\mathrm{g} / \mathrm{Kg}\end{array}$ & $37.3^{\mathrm{ab}}$ & $36.6^{\mathrm{ab}}$ & $33.2^{\mathrm{b}}$ & $40.2^{\mathrm{ab}}$ & $43.9^{\mathrm{a}}$ & $41.9^{\mathrm{ab}}$ & 1.45 & 0.031 \\
\hline OM (Kg/day) & 0.8 & 0.8 & 0.8 & 0.9 & 1.0 & 0.9 & 0.03 & 0.489 \\
\hline CP (Kg/day) & 0.2 & 0.2 & 0.2 & 0.2 & 0.2 & 0.2 & 0.03 & 0.521 \\
\hline NDF (Kg/day) & 0.5 & 0.5 & 0.5 & 0.5 & 0.6 & 0.6 & 0.03 & 0.612 \\
\hline ADF (Kg/day) & 0.3 & 0.3 & 0.3 & 0.3 & 0.3 & 0.3 & 0.03 & 0.452 \\
\hline $\mathrm{ADL}(\mathrm{Kg} /$ day & $0.4^{\mathrm{b}}$ & $0.4^{\mathrm{ab}}$ & $0.4^{\mathrm{ab}}$ & $0.4^{\mathrm{ab}}$ & $0.5^{\mathrm{ab}}$ & $0.6^{\mathrm{a}}$ & 0.02 & 0.024 \\
\hline Water (L/day) & \multicolumn{7}{|c|}{ Ingestive behaviour } & 0.456 \\
\hline $\begin{array}{l}\text { Chewing } \\
\text { (n/bolus) }\end{array}$ & $73.4^{\mathrm{ab}}$ & $71.5^{\mathrm{c}}$ & $72.0^{\mathrm{bc}}$ & $73.2^{\mathrm{b}}$ & $74.1^{\mathrm{a}}$ & $72.0^{\mathrm{bc}}$ & 0.39 & 0.005 \\
\hline $\begin{array}{l}\text { CR } \\
\text { (second/bolus) }\end{array}$ & $48.3^{\mathrm{bc}}$ & $48.4^{\mathrm{b}}$ & $50.1^{\mathrm{a}}$ & $49.2^{\mathrm{ab}}$ & $47.4^{\mathrm{c}}$ & $47.2^{c}$ & 1.90 & 0.005 \\
\hline \multicolumn{9}{|c|}{ Nutrient digestibility } \\
\hline $\mathrm{DM}(\%)$ & 84.8 & 82.5 & 86.2 & 86.2 & 87.5 & 87.0 & 3.53 & 0.357 \\
\hline $\mathrm{OM}(\%)$ & 87.2 & 85.4 & 88.4 & 88.1 & 89.3 & 89.3 & 3.06 & 0.457 \\
\hline $\mathrm{CP}(\%)$ & 93.4 & 92.0 & 93.9 & 93.6 & 93.8 & 94.3 & 1.89 & 0.215 \\
\hline $\mathrm{EE}(\%)$ & 99.0 & 98.2 & 99.5 & 98.0 & 98.5 & 99.0 & 1.05 & 0.735 \\
\hline $\operatorname{NDF}(\%)$ & 74.8 & 74.1 & 82.1 & 77.5 & 78.1 & 84.0 & 5.52 & 0.302 \\
\hline \multicolumn{9}{|c|}{ Performance } \\
\hline IBW (Kg) & 16.4 & 16.0 & 16.7 & 16.0 & 16.0 & 17.2 & 2.07 & 0.258 \\
\hline $\begin{array}{l}\text { Final body } \\
\text { weight }(\mathrm{Kg})\end{array}$ & 29.3 & 29.1 & 30.1 & 31.1 & 32.4 & 29.6 & 2.00 & 0.236 \\
\hline $\begin{array}{l}\text { Total weight } \\
\text { gain }(\mathrm{Kg})\end{array}$ & 13.0 & 13.1 & 13.4 & 15.1 & 16.4 & 12.4 & 2.08 & 0.165 \\
\hline ADG (g/day) & 145.7 & 146.8 & 150.6 & 170.2 & 184.5 & 139.7 & 2.08 & 0.165 \\
\hline
\end{tabular}

Means compared on the same line do not differ by the Tukey test $(P>0.05)$. CR - Chewing rate; IBW - initial body weight; ADG - average daily gain.

The straw-hay of different grasses incorporated into the diet did not have an effect on the weight gain of the animals $(P>0.05)$ (Table 3$)$. In addition, this straw-hay in lamb diet did not have any effect on the length of the carcass, length of the leg, width and perimeter of the croup, depth of the chest or weight of the left half of the carcass $(P>0.05)$. There were effects of cultivar straw-hay on the fat distribution $(P=0.020)$ which presented an average ranging from 1.50 for the Massai cultivar to 2.58 for the Tupi cultivar; and subcutaneous fat thickness (SFT), which lambs fed with diet containing Massai straw-hay presented the highest $(P=0.041)$ average $(2.0 \mathrm{~mm})$, and diet with Tupi straw-hay the smallest SFT $(0.3 \mathrm{~mm})$, respectively. Likewise, there were effects of cultivar straw-hay on the meat characteristic. The carcass of the lambs fed with Mombaça straw-hay showed highest $(P=0.012)$ bone proportion $(346.6 \mathrm{~g} / \mathrm{kg})$ and smallest $(P=0.009)$ muscle proportion $(385 \mathrm{~g} / \mathrm{kg})$ while presented high $(P=0.036)$ fat proportion $(268.4 \mathrm{~g} / \mathrm{kg})$. Lambs fed with diet containing Marandu straw-hay presented highest muscle proportions $(480.5 \mathrm{~g} / \mathrm{kg})$ and smallest bone proportion $(300.8 \mathrm{~g} / \mathrm{kg})$, respectively. There was a significant effect of diet containing differ straw-hays on fat distributions in the diets resulted in greater subcutaneous fat thicknesses $(2.05 \mathrm{~mm})$ for Massai and $0.32 \mathrm{~mm}$ for Tupi, respectively. 
Table 3. The carcass characteristics of lambs fed diets containing straw-hay from the cultivars of Brachiaria and Panicum in the diet

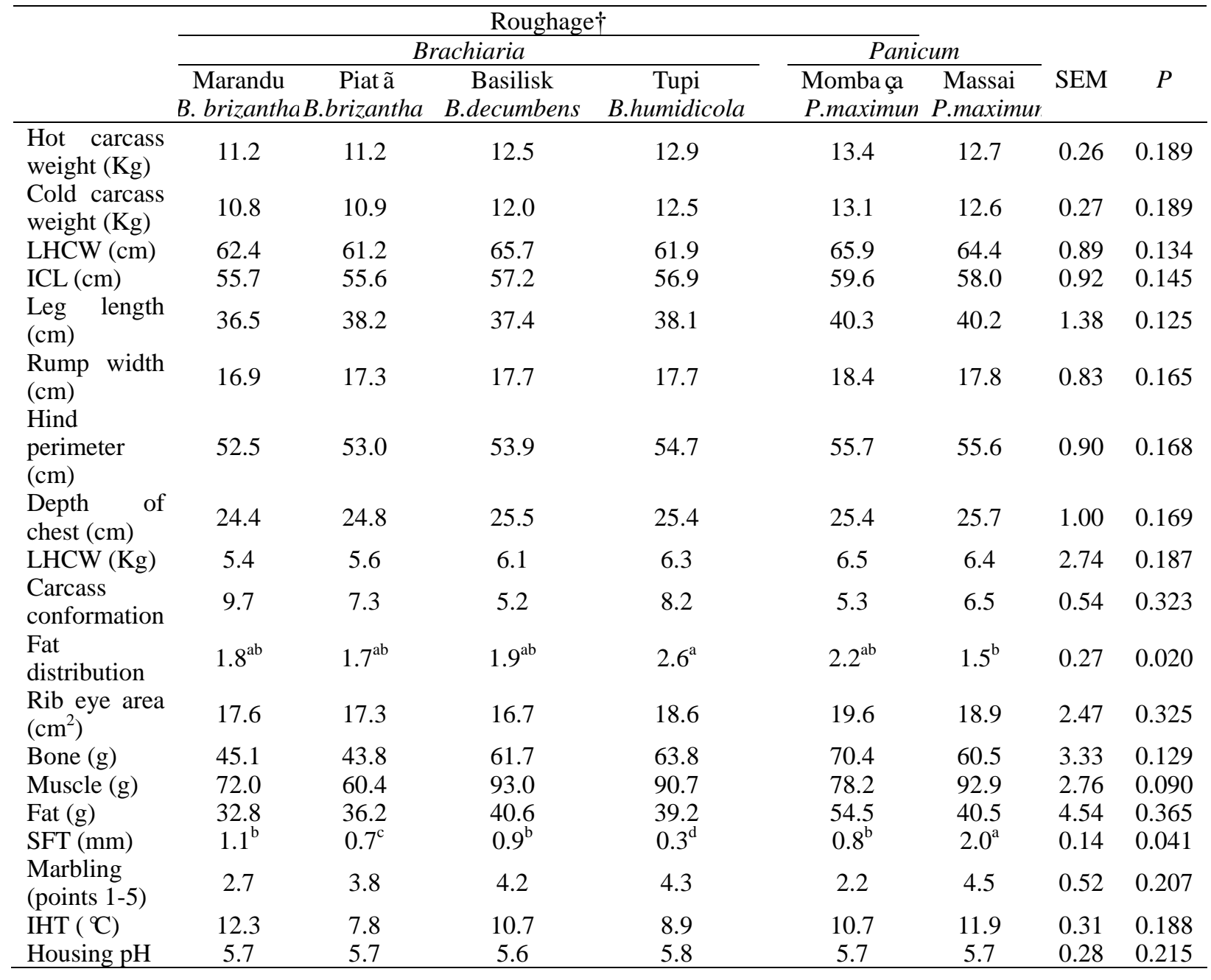

$\dagger$ Means were compared on the same line and do not differ by Turkey's test $(P>0.05)$. ICL internal carcass length; LHCW - left half of the carcass weight; SFT - Subcutaneous fat thickness; IHT - internal housing temperature

The weights and yields of the commercial cuts (Table 4$)$ were not affected $(P>0.05)$ by the different cultivars of hay. The averages of cuts yield were $0.52 \mathrm{~kg}(8.6 \%)$ for the neck, 1.25 $\mathrm{kg}(22.6 \%)$ for the Palette, 0.74 (12.6\%) for the T-bone and $1.17 \mathrm{~kg}(19.3 \%)$ for the ribs, and the highest yield was observed for the gammon $(1.97 \mathrm{~kg}, 32.6 \%)$ and the lowest yield was observed for the loin $(0.40 \mathrm{~kg}, 6.6 \%)$. Among the carcass components, the gammon accounted for the highest proportion $(32.6 \%)$. 
Table 4. Cut yields of lambs fed by diets containing straw-hay from the cultivars of Brachiaria sp. and Panicum sp. in the diet

\begin{tabular}{|c|c|c|c|c|c|c|c|c|}
\hline & \multicolumn{6}{|c|}{ Roughage $\dagger$} & \multirow{3}{*}{ SEM } & \multirow{3}{*}{$P$} \\
\hline & \multicolumn{4}{|c|}{ Brachiaria } & \multicolumn{2}{|c|}{ Panicum } & & \\
\hline & $\begin{array}{c}\text { Marandu } \\
\text { B.brizantha }\end{array}$ & $\begin{array}{c}\text { Piatã } \\
\text { B.brizantha }\end{array}$ & $\begin{array}{c}\text { Basilisk } \\
\text { B.decumbens }\end{array}$ & $\begin{array}{c}\text { Tupi } \\
\text { B.humidicola }\end{array}$ & $\begin{array}{c}\text { Mombaça } \\
\text { P.maximum }\end{array}$ & $\begin{array}{c}\text { Massai } \\
\text { P.maximum }\end{array}$ & & \\
\hline $\begin{array}{l}\text { Neck } \\
(\mathrm{Kg})\end{array}$ & 0.5 & 0.5 & 0.5 & 0.5 & 0.6 & 0.6 & 0.31 & 0.265 \\
\hline $\begin{array}{l}\text { Palette } \\
(\mathrm{Kg})\end{array}$ & 1.0 & 1.1 & 1.5 & 1.6 & 1.2 & 1.0 & 0.43 & 0.237 \\
\hline $\begin{array}{l}\text { T-bone } \\
\text { (Kg) }\end{array}$ & 0.7 & 0.7 & 0.7 & 0.7 & 0.8 & 0.8 & 0.32 & 0.221 \\
\hline $\mathrm{Rib}(\mathrm{Kg})$ & 1.0 & 1.0 & 1.2 & 1.3 & 1.3 & 1.1 & 0.33 & 0.236 \\
\hline $\begin{array}{l}\text { Loin } \\
(\mathrm{Kg})\end{array}$ & 0.4 & 0.4 & 0.4 & 0.5 & 0.4 & 0.4 & 0.27 & 0.241 \\
\hline $\begin{array}{l}\text { Gammon } \\
(\mathrm{Kg})\end{array}$ & 1.8 & 1.9 & 1.7 & 1.9 & 2.2 & 2.2 & 0.26 & 0.232 \\
\hline $\begin{array}{l}\text { Neck } \\
(\mathrm{g} / \mathrm{Kg})\end{array}$ & 84 & 89 & 75 & 82 & 94 & 89 & 3.13 & 0.265 \\
\hline $\begin{array}{l}\text { Palette } \\
\text { (g/Kg) }\end{array}$ & 195 & 189 & 251 & 254 & 189 & 160 & 43.18 & 0.237 \\
\hline $\begin{array}{l}\text { T-bone } \\
\text { (g/Kg) }\end{array}$ & 126 & 130 & 120 & 111 & 127 & 124 & 32.57 & 0.221 \\
\hline $\begin{array}{l}\text { Rib } \\
(\mathrm{g} / \mathrm{Kg})\end{array}$ & 193 & 180 & 192 & 213 & 201 & 179 & 33.04 & 0.236 \\
\hline $\begin{array}{l}\text { Loin } \\
(\mathrm{g} / \mathrm{Kg})\end{array}$ & 69 & 63 & 69 & 73 & 61 & 64 & 2.73 & 0.241 \\
\hline $\begin{array}{l}\text { Gammon } \\
(\mathrm{g} / \mathrm{Kg})\end{array}$ & 338 & 343 & 282 & 308 & 337 & 350 & 26.95 & 0.232 \\
\hline
\end{tabular}

$\dagger$ Means were compared on the same line and do not differ by Turkey's test $(P>0.05)$.

\section{Discussion}

The lambs exhibited a similar average daily weight gain (Table 3 ) because lignin content in straw-hays is a constituent of NDF, a structural carbohydrate that lowers the cellular content and affects the size and digestion rate of ruminants (Silva et al. 2015a). However, presented high chewing rate, mostly that straw-hay with high NDF and lignin contents.

The average daily gain found in this study (156.24 g/day) was lower than the gains observed by other authors (Ribeiro et al. 2011; Carvalho et al. 2015; Oliveira et al. 2015a). In the lambs, with previous studies recording an average daily gain of over $200 \mathrm{~g} / \mathrm{day}$, which may be related to the forage source. Straw-hay can be is an excellent roughage reservation strategy and improves the efficiency of the rumen system, which is a fundamental strategy in ruminant nutrition to promote better performance associated with a reduction in environmental impacts.

Nevertheless, the quality of roughage is an important factor in the diet that can influence the consumption and utilization of nutrients by the ruminants (Tafaj et al. 2005) and, indigestible fiber is a determining factor in the quality of roughage because the largest fiber is usually associated with a low ruminants degradation rate and an increased rumination time because it reduces the passage rate, digestibility and nutrient intake (Van Soest, 1994).

In this experiment, the similarity between the nutritional quality of the consumed straw-hay 
led to similar performances between treatments but performances below what is observed in the literature (Ribeiro et al. 2011; Carvalho et al. 2015; Oliveira et al. 2015a). This results which might be associated with roughage: concentrate ratio $(500: 500 \mathrm{w} / \mathrm{w})$ utilized here because most experiments with lambs use roughage: concentrate ratio of 600:400 to 700:300 $\mathrm{w} / \mathrm{w}$, in addiction of fiber source. Because the animal performance is dependent on consumption, similarities were also observed in the morphometric measurements.

Average of fat distribution $(1.76 \mathrm{~mm})$ was consistent with the findings by Macedo et al. (2008) who studied performance and carcass traits of lambs fed diets containing sunflower seed. Fat depositions in the carcass occur rapidly near the loin and rib (Fernandes et al. 2011). Osório (1992) reported a relationship between the regional tissue composition and carcass composition of lambs because the increased proportion of fat in the carcass is associated with an increased proportion of the rib, whereas a greater proportion of muscle in the carcass is associated with an increased proportion of the leg. This result represents a positive aspect for production because a large proportion of the leg adds production value, and according to Pilar et al. (2006), different carcass cuts have different economic values, with the leg or ham the most valuable cuts. Therefore, the ratios of these cuts represent important indices to evaluate the commercial carcass quality. Moreover, a suitable confirmation indicates the proportional development of distinct anatomical regions of the body, and the best confirmations are achieved when the regions of commercial value are well-developed, even if these values are subjective estimates according to visual inspection.

\section{Conclusion}

The results of the present study show diets isoprotein $(170 \mathrm{~g} / \mathrm{kg})$ with a $500: 500 \mathrm{w} / \mathrm{w}$ roughage: concentrate proportion of Brachiaria sp. or Panicum sp. Straw-hay did not have an effect on the dry matter and crude protein consumption together with the growth performance. However, it can modify the carcass characteristics and cut yields in lambs. So, we can recommend the residue of seed harvest (straw) from tropical grasses as a fiber source to feedlot lamb diet to obtain sustainability in agricultural and food systems by use of this by-product.

\section{References}

Ahmed, M. H., Salem, A. Z. M., Zeweil, H. S., Sun, X. Z., Kholif, A. E., Elghandour, M. M. Y., \& Bahar, M. S. I. (2015). Growth performance and carcass characteristics of lambs fed halophytes as a partial or whole replacement of berseem hay. Small Ruminant Research, 128, 1-9. https://doi.org/10.1016/j.smallrumres.2015.05.004

Association of Official Analytical Chemists AOAC. (2000). Official Methods of Analysis, Arlington, VA, USA: Association of official analytical chemists 2002.

Association of Official Analytical Chemists AOAC. (2002). Official methods of analysis. 12t $\mathrm{h}$ ed. Arlington, VA, USA: Association of official analytical chemists.

Cartaxo, F. Q., Cezar, M. F., Sousa, W. H., Gonzaga, N. S., Pereira, F. J. M., \& Cunha, M. G. G. (2009). Quantitative traits of carcass from lambs finished in feedlot system and 
slaughtered at different body conditions. Revista Brasileira de Zootecnia, 38, 697-704. https://doi.org/10.1590/S1516-35982009000400016

Carvalho, Z. G., Silva, F., Araújo, A. R., Alves, D. D., Oliveira, L. L. S., Reis, S. T., \& Silva, V. L. (2015). Meat cuts and non-carcass constituents of grass-fed sheep with different levels of supplementation. Semina: Ciências Agrárias, 36, 409-419.

https://doi.org/10.5433/1679-0359.2015v36n1p409

Conselho Federal de Medicina Veterinária. (2010). Brazilian Federal Council of Veterinary Medicine. Ethics Committee, Bioethics and Animal Welfare. Universal Declaration of Animal Rights. http://www.cfmv.org.br/portal/direitos_animais.php

Fernandes, A. R. M., Orrico Junior, M. A. P., Orrico, A. C. A., Vargas Junior, F. M., \& Oliveira, A. B. M. (2011). Performance and qualitative characteristics of carcasses and meat of lambs finished in confinement and fed diets containing soybean grain or protected fat. Revista Brasileira de Zootecnia, 40, 1822-1829.

https://doi.org/10.1590/S1516-35982011000800028

Fernandes, L. O., Reis, R. A., Paes, J. M. V., Teixeira, R. M. A., Queiroz, D. S., \& Paschoal, J. J. (2015). Performance of Gir young bull maintained in "Brachiaria brizantha" pastures submitted to different management. Revista Brasileira de Saúde e Produção animal, 16, 36-46. https://doi.org/10.1590/S1519-99402015000100004

Lima, R. M. B., Sousa, W. H., Medeiros, A. N., Cezar, M. F., Cartaxo, F. Q., Gonzaga Neto, S., ... Medeiros, G. R. (2015). Characteristics of the carcass of goats of different genotypes fed pineapple (Ananas comosus L.) stubble hay. Revista Brasileira de Zootecnia, 44, 44-51. https://doi.org/10.1590/s1806-92902015000200002

Macedo, V. P., Silveira, A. C., Garcia, C. A., Monteiro, A. L. G., Macedo, F. A. F., \& Spers, R. C. (2008). Performance and carcass traits of lambs fed diets containing sunflower seed in creep feeding. Revista Brasileira de Zootecnia, 37, 2041-2048.

https://doi.org/10.1590/S1516-35982008001100021

Moreira, M. N., Silva, A. M. A., Carneiro, H., Bezerra, L. R., Morais, R. K. O., \& Medeiros, F. F. (2014). In vitro degradability and total gas production of biodiesel chain byproducts used as a replacement for cane sugar feed. Acta Scientiarum. Animal Sciences, 36, 399-403. https://doi.org/10.4025/actascianimsci.v36i4.23950

National Research Council - NRC. (2007). Nutrient requirements of small ruminants: sheep, goats, cervids and new world camelids. Washington: National Academy Press, 362p. https://doi.org/10.17226/11654

Oliveira, L. S., Mazon, M. R., Carvalho, R. F., Pesce, D. M. C., Silva, S. L, Gallo, S. B., \& Leme, P. R. (2015b). Effects of processing corn on the carcass traits and meat quality of feedlot. Tropical Animal Health and Production, 47, 883-887.

https://doi.org/10.1007/s11250-015-0803-x

Oliveira, R. L., Palmieri, A. D., Carvalho, S. T., Leão, A. G., Abreu, C. L., Ribeiro, C. V. D. 
M., ... Bezerra, L. R. (2015a). Commercial cuts and chemical and sensory attributes of meat from crossbred Boer goats fed sunflower cake-based diets. Animal Science Journal, 86, 557-562. https://doi.org/10.1111/asj.12325

Osório, J. C. (1992). Estudio de la calidad de canales comercializadas en el tipo ternasco según la procedencia: bases para la mejora de dicha calidad en Brasil. [Study of the quality of commercialized channels in the Ternasco type according to provenance: bases for the improvement of this quality in Brazil. Universidad de Zaragoza, Zaragoza. Spanish.

Osório, J. C., De Oliveira, N. M., Jardim, P. O., \& Monteiro, E. M. (1996a). Meat production in sheep of five genotypes. 2. Live weight components. Ciência Rural, 26, 471-475. https://doi.org/10.1590/S0103-84781996000300023

Osório, J. C., De Oliveira, N. M., Nunes, A. P., \& Pouey, J. L. (1996b). Meat production in sheep of five genotypes. 3. Losses and morphology. Ciência Rural, 26, 477-481. https://doi.org/10.1590/S0103-84781996000300024

Pilar, R. C., Pérez, J. R. O., \& Nunes, F. M. (2006). Relative composition of carcass cuts of Australian Merino lambs and crosses Ile de France vs. Australian Merino slaughtered with different weights. Revista Brasileira Agrociência, 12, 461-469.

Ribeiro, R. D. X., Oliveira, R. L., Macome, F. M., Bagaldo, A. R., Silva, M. C. A., Ribeiro, C. V. D. M., ... Lanna, D. P. D. (2011). Meat quality of lambs fed on palm kernel meal, a by-product of biodiesel production. Asian Australasian Journal of Animal Sciences, 24, 1399-1406. https://doi.org/10.5713/ajas.2011.11110

Robertson, J. B., \& Van Soest, P. J. (1981). The detergent system of analysis, in: James WPT, Theander O. (Ed.). The Analysis of Dietary Fiber in Food. Marcel Dekker, 1981. New York, pp. $123-158$.

SAS Institute, Inc. 2002. SAS/STAT user's guide. SAS Institute, Cary, NC, USA.

Silva, A. M. A., Alves, S. V., Bezerra, L. R., Carneiro, H., Oliveira, R. L., Medeiros, F. F., ... Araújo, D. R. C. (2015b). Potential in vitro degradability and gas production of the byproducts of the biodiesel chain. Ciencia e Investigación Agraria, 42, 285-293. https://doi.org/10.4067/S0718-16202015000200014

Silva, F. V., Carvalho, Z. G., Sá, H. C. M., Oliveira, L. L. S., Alves, D. D., Silva, V. L., ... Santos, C. C. R. (2014). Weight gain, carcass and meat traits of ewes finished on pasture with different levels supplementation. Revista Brasileira de Saúde e Produção Animal, 15, 206-220. https://doi.org/10.1590/S1519-99402014000100022

Silva, T. P. D., Marques, C. A. T., Torreao, J. N. C., Bezerra, L. R., Araujo, M. J., Gottardi, F. P., ... Oliveira, R. L. (2015a). Ingestive behaviour of grazing ewes given two levels of concentrate. South African Journal of Animal Science, 45, 180-187. https://doi.org/10.4314/sajas.v45i2.9

Sniffen, C. J., O’Connor, J. D., Van Soest, P. J., Fox, D. G., \& Russell, J. B. (1992). A net carbohydrate and protein system for evaluating cattle diets. 2. Carbohydrate and protein 


\section{Macrothink}

Journal of Agricultural Studies

ISSN 2166-0379 2019, Vol. 7, No. 4

availability. Journal of Animal Science, 70, 3562-3577.

https://doi.org/10.2527/1992.70113562x

Tafaj, M., Maulbetsch, A., Zebeli, Q., \& Steingass, H. (2005). Effects of physically effective fiber concentration of diets consistin of hay and slowly degradable concentrate on chewing activity in mid lactation dairy cows under constant intake level. Archives of Animal Nutrition, 59, 313-324. https://doi.org/10.1080/17450390500247840

Van Soest, P. J. (1994). Nutritional ecology of the ruminant. 2nd Ed. New York: Cornell University Press, p. 476.

\section{Copyright Disclaimer}

Copyright for this article is retained by the author(s), with first publication rights granted to the journal.

This is an open-access article distributed under the terms and conditions of the Creative Commons Attribution license (http://creativecommons.org/licenses/by/4.0/). 